CSDM Views 20

\title{
Management Priorities of the Minister of Defence of the Republic of Bulgaria in the 2013 Caretaker Government
}

Todor Tagarev

January $2014 r$. 


\section{Todor Tagarev, Management Priorities of the Minister of Defence of the Republic of Bulgaria in the 2013 Caretaker Government}

Abstract: Defence governance principles, priorities, and tasks of minister Tagarev as member of Bulgaria's Caretaker Government, appointed by President Rossen Plevneliev, and his team, aim to provide stability of the defence sector and military operations, open dialogue with the organizations active on defence policy issues, and enhanced cooperation and interaction with our Allies and national security sector organizations. These priorities were publicly announced on 20 March 2013.

Keywords: stability, cooperation, coordination, transparency, accountability, integrity

\section{Тодор Тагарев, Управленски приоритети на министъра на отбраната на Република България в Служебното правителство 2013}

Резюме: Представени са управленските принципи, приоритети и задачи на министър Тагарев като член на Служебното правителство, назначено от Президента Росен Плевнелиев, и неговият екип, насочени към осигуряване на стабилност и устойчивост в управлението на отбранителния сектор, открит диалог с организациите, активни по въпроси на отбранителната политика, задълбочено сътрудничество и взаимодействие със съюзниците и организациите от националния сектор за сигурност. Приоритетите за обявени публично на 20 март 2013 г.

Ключови думи: устойчивост, взаимодействие, координация, прозрачност, отчетност, интегритет

Editors: Todor Tagarev, Velizar Shalamanov, Venelin Georgiev, Valeri Ratchev 
Following the failure of the 41st National Assembly to form a Government, after the previous one resigned, the President of the Republic of Bulgaria, pursuant to the provisions of the Constitution, appointed a Caretaker Government. The main tasks of this Government are to ensure stability, to work towards building confidence in the institutions, higher levels of transparency and citizens' control, and to guarantee free and democratic elections.

The Caretaker Government will work until the formation of a new government after the Parliamentary elections on 12 May 2013, will not be entitled to legislative initiative and will act within the framework of the Law on the State Budget, adopted by the 41st National Assembly.

Committed to the implementation of the Constitution and the legislation of the Republic of Bulgaria, my team, closely interacting with the military and administrative leadership of the Ministry of Defence, will focus its efforts on the achievement of realistic goals, strictly adhering to the following

\section{PRINCIPLE}

- Dialogue with the society and the citizens in the defence policy shaping;

- Interaction with professional, academic and public organizations and business associations working on defence policy issues;

- Coherence between intentions, decisions and actions;

- Maximum transparency of decisions and actions;

- Accountability for the achieved outcomes;

- Systemic assessment of defence management risk and prioritization of mitigation measures.

The main priorities are to ensure stability of control and governance of the defence sector, hold open dialogue with the organizations active on defence policy issues, and enhance cooperation and interaction with our Allies and national security sector organizations.

The main tasks reflecting these three priorities are as follows:

\section{Stability and Rule of Law}

\section{Development of the Armed Forces in compliance with the endorsed strategic documents}

The stability of the defence sector will be provided through regular and persistent control of the contingents on missions and troops on duty, implementation of the strategy for transforming the participation of the Armed Forces of the Republic of Bulgaria in the operation of the NATO-led International Security Assistance Force in Afghanistan, continuing transformation of the Armed Forces in accordance with the decisions of the National Assembly and the approved development plans.

\section{Provision of an opportunity for service members' voting and fair elections}

Service members participating in missions and operations out of the territory of the country and on duty will be able to exercise their constitutional right to vote in the parliamentary elections. To this end, implementation of the provisions of the Election Code will be carried out in the respective sections. All required measures will be taken to guarantee the security of the participants in the election process. 


\section{Dialogue, Respect, Integrity}

3. Enhancement of the dialogue with professional, academic and societal organizations and business associations working on defence policy issues

A Public Council on Defence Policy will be established where thematic discussions will be organized. We will launch an online platform to promote this dialogue and will publish positions, statements and proposals of Council members.

4. Balancing military and civil expertise and stabilizing the management processes in the integrated Ministry of Defence

We will work towards the promotion of the principles of distribution and sharing of powers and responsibilities of the political, military and administrative leadership and respect for the contribution and expertise of each of the three groups.

\section{Fostering the integrity of the defence organization}

Based on a systemic review, a Corruption Risk Map will be developed. We will elaborate short-term and mid-term plans for mitigating corruption risks and will launch key measures for the prevention of conflict of interests and corruption in the defence sector..

\section{Cooperation and Interaction}

\section{Effective involvement in NATO's Smart Defence and the EU Pooling \&Sharing initiatives}

We will actively continue the consultations in NATO on the package of Capability Targets 2013. The long-term Smart Defence and Pooling \&Sharing projects will be analysed and prioritized in order to assume realistic commitments for valuable, effective and efficient contribution to NATO and the EU Common Security and Defence Policy.

7. Promotion of the mechanisms of interaction between security sector institutions and public-private partnerships

We will aim at modern, network interaction in cyber security solutions. Together with partner organizations, we will develop the foundation of a national Cyber Security Strategy and a Programme for Development of Cyber Defence Capabilities, in particular through effective involvement in NATO and EU cutting-edge technology initiatives and projects. We are considering the possibility to establish a cyber-defence unit within the Armed Forces Reserve.

Our success in fulfilling these tasks depends to a great extent on the sharing of common principles, the commitment and the energy of all service members and defence civilians. We believe that our joint efforts will lead to a better awareness in the society of the role of the Armed Forces in the 21st century and the challenges to the military profession. At the same time, the Armed Forces will have better grounds to address future requirements and implement smart solutions jointly with our NATO allies and EU partners. 